\title{
Review
}

\section{T cell targeting in cancer therapy}

\author{
Reinder L. H. Bolhuis, Els Sturm, and Eric Braakman \\ Department of Immunology, Dr. Daniel den Hoed Cancer Center, Rotterdam, The Netherlands
}

Received 24 June 1991/Accepted 2 July 1991

\begin{abstract}
Summary. Targeting of immune cells by bispecific antibodies has proven a powerful tool for the investigation of cellular cytotoxicity, lymphocyte activation and induction of cytokine production, as well as to represent an innovative form of immunotherapy for the treatment of cancer. The hallmark of this approach is the use of the specificity of monoclonal antibodies to join target and immune cells by virtue of the dual specificity of bispecific antibodies for the two entities. More precisely the bispecific antibody has two different binding sites, which are capable of recognizing tumor associated antigens on the one hand and lymphocyte activation sites on the other. This process of crosslinking results in the activation of the lymphocyte and triggering of its lytic machinery, as well as lymphokine production. A major advantage of this therapeutic modality is, that use is made of the normal cellular immune defence system and therefore is only associated with minor toxicity. The distinct lymphocyte populations, which can be used for adoptive immunotherapy and the various bispecific antibody preparations, as well as the chimeric immunoglobulin/T cell receptor construction are the major topics of this review.
\end{abstract}

Key words: $\mathrm{T}$ lymphocytes - Bispecific antibody Cancer therapy

\section{Introduction}

The vertebrate immune system can eliminate and neutralize virtually any foreign invader and distinguish such antigens from the body's own. To this end we possess two major classes of immune responses: the humoral and the cellular responses. The humoral response is mediated by antibodies that are produced by B lymphocytes upon specific antigen recognition. The binding of antibody to antigen facilitates the elimination of the invader by other immune cells. The cellular response involves specialized cells such as T lymphocytes and non-specific natural killer (NK) cells, monocytes, macrophages and granulocytes. The $\mathrm{T}$ lymphocyte population can be divided into two mutually exclusive subpopulations, i.e. $\operatorname{TCR} \alpha \beta$ and TCR $\gamma \delta$ lymphocytes.

Experimentally induced tumour cells can express new antigens $(\mathrm{Ag})$ on their surface. Such $\mathrm{Ag}$ are unique or selective and may be immunogenic and thus elicit a tumour-specific cytotoxic T lymphocyte (CTL) response. The study of tumour-specific immune reactions was stimulated by the postulation of immune surveillance as formulated by Ehrlich in 1909 [31], and adapted by Burnet in 1970 [23]. The keynote of the hypothesis is that antigenspecific $\mathrm{T}$ lymphocytes are the critical surveillance cells that arrest or eliminate cancer cells from the host. In general, specific $T$ cells recognize their antigen in the context of the major histocompatibility complex (MHC) on the surface of the Ag-presenting cell. In experimentally induced tumour models such MHC-restricted tumour-specific T cells have been identified. In humans, "tumour-specific" CTL, which are not MHC-restricted, also have been demonstrated $[22,110]$.

Most efforts, however, to produce human CTL specific for human tumours have failed. Therefore the discovery that $T$ cells can be recruited and targeted to a tumour cell by either bispecific antibodies (bs-mAb) or by equiping them with chimeric immunoglobulin/ $T$ cell receptors (Ig-TCR) has drawn considerable attention. These two strategies allow the focussing of immune effector cells to tumour cells and hold great promise for immunotherapy.

\section{CTLtarget cell interaction.}

The interaction between a cytotoxic lymphocyte and a target cell can be divided into several stages $[8,67,68]$. The initial adhesion step is the rapid formation of an intercellular bond. Because CTL also bind to target cells that do not express the relevant MHC/antigen complex, and antiTCR monoclonal antibodies $(\mathrm{mAb})$ can not inhibit the 
initial binding step, it was concluded that the initial interaction does not involve a specific TCR/antigen interaction [94]. Blocking studies with $\mathrm{mAb}$ against cell-surface molecules have identified two major pathways of antigen non-specific interactions [88]. First, leucocyte function-associated antigen-1 (LFA-1 or CD11/18 a) on the surface of the effector cell interacts with intercellular adhesion molecule (ICAM)-1 (CD54) or ICAM-2 [64, 65, 88, 96, 98]. Secondly, CD2 on the effector lymphocyte interacts with LFA-3 (CD 58) on the target cell $[49,87,88]$. When present on the surface of the cytotoxic lymphocyte, CD4 and CD8 may also contribute to this initial adhesion by binding to MHC class II or class I molecules respectively $[83,92,93]$. The initial adhesion phase is dependent on the presence of $\mathrm{Mg}^{2+}$ [88]. The second stage of the cytotoxic process consists of target cell recognition, which results in stabilization of the interaction between the effector- and the target cell, and leads to effector cell activation. Target cell recognition and activation of $T$ cells occur through the TCR/CD3 complex, in which the TCR is responsible for the antigen recognition and the CD3 molecule for the transduction of signals generated by the TCR-antigen interaction [25].

Stabilization of the interaction between the effector cell and the target cell is not only due to the extra TCR-antigen bond. TCR crosslinking also results in a transient conformational change of the LFA-1 molecule. Consequently, the LFA-1 mediated adhesion temporarily increases $[30,52]$.

In fact, crosslinking of TCR/CD3 complexes at the cellcell contact region also induces changes in the conformation and distribution of other cell surface molecules: TCR/CD3 crosslinking induces the redistribution of CD4 or CD8 molecules, which lead these molecules towards the contact region, where they become physically associated with the TCR/CD 3 complexes $[11,55,85]$. The intracellular domains of CD4/CD8 antigens are also physically associated with the lymphocyte specific tyrosine protein kinase (TPK) p56lck. This TPK plays an important role in $T$ cell activation, by phosphorylation of the $\zeta$ chain of the TCR/CD3 complex.

The CD4/CD8 molecules, that are physically associated with TCR/CD3 complexes, are believed to bind to the same $\mathrm{MHC}$ molecule that presents the antigen, leading to an increased CTL-target cell binding and optimal CTL activation $[4,85]$. Taken together, it is clear that the co-clustering of TCR/CD3 with various other adhesion/signal transduction molecules at the cell-cell contact region, and their physical and functional interactions, critically control activation of the effector lymphocyte. The third stage of the cytotoxic process consists of the delivery of the lethal hit to the target cell and subsequent target cell death [114]. After delivery of the lethal hit, the effector lymphocyte dissociates from the target cell and may bind to another, a process that is referred to as recycling $[67,68]$.

\section{TCR $\alpha \beta$ and $\gamma \delta$ lymphocytes}

The availability of anti-TCR/CD3 $\mathrm{mAb}$ has facilitated the elucidation of the protein structure of this receptor complex $[28,44,66]$.
The TCR+ lymphocyte population comprises of two distinct lymphocyte populations which are both capable of exerting cell-mediated cytotoxicity:

1. T lymphocytes that express an antigen-receptor, that is a disulphide-linked heterodimer composed of an $\alpha$ and a $\beta$ protein: TCR $\alpha \beta$ lymphocytes [15].

2. T lymphocytes with an antigen-receptor composed of a $\gamma$ and a $\delta$ protein. The $\gamma$ and $\delta$ chains can be either disulphide or nondisulphide linked: TCR $\gamma \delta$ lymphocytes $[16,20]$.

The TCR $\alpha$ and $\beta$ genes encode transmembrane glycoproteins whose sequences are homologous to those of $\mathrm{Ig}$ $[45,113]$. Together, the TCR $\alpha$ and $\beta$ chains determine the specificity of the TCR $\alpha \beta$ lymphocytes $[29,84]$. The TCR itself is thought not to be involved in signal transduction. In fact, the TCR molecules are non-covalently associated with the CD3 molecular complex, which represent the signal-transducing structure $[19,74,90]$.

T lymphocytes can also be activated by anti-TCR/CD3 $\mathrm{mAb}$. For activation to occur the $\mathrm{mAb}$, and thereby the TCR/CD3 complexes, need to become crosslinked. Such Ab-induced $\mathrm{T}$ cell activation is polyclonal [61]. Crosslinking of the TCR/CD3 complex, either by antigen-specific stimulation or by anti-TCR/CD3 $\mathrm{mAb}$, initiates signal transduction and leads to full $\mathrm{T}$ cell activation, expression of the interleukin-2 receptor (IL-2R), production of lymphokines, cytolytic activity, and proliferation. As described, most TCR $\alpha \beta$ lymphocytes express either the CD4 or CD8 molecules. The helper/inducer functions are exhibited by $\mathrm{CD}^{+}+$lymphocytes, whereas $\mathrm{CD}^{+}$, and a minority of CD4+, lymphocytes exert cytolytic activities $[36,63,77]$. The antigen specific recognition by $\mathrm{CD}^{+}$ lymphocytes is restricted by $\mathrm{MHC}$ class II antigens, whereas that of $\mathrm{CD} 8+$ lymphocytes is restricted by MHC class I molecules [101]. The CD4/CD8 glycoproteins play distinct functions in $\mathrm{T}$ cell activation. Again, they stabilize or increase the avidity of the interaction of the TCR/CD3 complex and the Ag-MHC by binding to the same MHC molecule that presents the antigen. However they also play an important role as an independent signal transducing element.

The cells of the minor TCR $\gamma \delta$ lymphocyte fraction, (3\%-4\% of the TCR + lymphocytes) virtually all lack the expression of CD4 or CD8 antigens [16, 53, 99, 106]. Freshly isolated TCR $\gamma \delta$ lymphocytes do not lyse NK susceptible target cells. Upon in vitro activation, TCR $\gamma \delta 1 \mathrm{ym}$ phocytes can exert MHC-unrestricted cytolysis towards a variety of tumor cells of distinct histologic origin, which does not involve the TCR. Antigen specific TCR $\gamma \delta 1 \mathrm{ym}-$ phocytes have also been identified. Some of the identified Og are CD1c, TCT-1, HLA-A2, A23, DR7 and Dw6 [95]. TCR $\gamma \delta$ lymphocytes can be divided on the basis of their functional rearrangements into two distinct subsets. The $\mathrm{V} \gamma 9-\mathrm{V} \delta 2$ encoded TCR $\gamma \delta$ heterodimer is the predominant receptor type in peripheral blood, whereas the $V \delta 1$ encoded TCR $\gamma \delta$ heterodimer represents a minor population [99]. These distinct TCR $\gamma \delta$ subpopulations show also distinct MHC unrestricted activity towards superantigens [35, 100]. Superantigens are defined as structures that activate a total lymphocyte population which uses one particular $\mathrm{V}$ gene element. 


\section{Natural killer cells}

NK cells are lymphoid cells with typical "large granular lymphocyte" (LGL) morphology, and represent approximately $10 \%$ of peripheral blood lymphocytes (PBL). NK cells are functionally defined by their ability to display cytotoxicity against various target cells without prior activation $[46,75,103]$. They do not productively transcribe TCR genes $[9,58]$. Therefore, their lytic activity is MHCunrestricted. By definition, NK cells lack a memory response. In addition to their cytotoxic activity, a wide variety of non-cytotoxic functions have been identified, e.g. the production of a plethora of cytokines in response to stimulation with lectins, viruses, bacteria or NK susceptible target cells. The lymphokines produced by NK cells include interferon $\alpha$ and interferon $\gamma$ (IFN $\alpha$, IFN $\gamma)$, IL-1, IL-2, natural killer cytotoxic factor, lymphotoxin and colony stimulation factor (CSF). The capacity to produce this plethora of lymphokines illustrates their important immunoregulatory role for NK cells [2, 80, 104, 112].

NK cells commonly express CD2, CD16 and NKHI (CD56) membrane antigens [81]. In contrast to TCR $\alpha \beta$ lymphocytes, single anti-CD2 mAb preparations can induce cytotoxicity by NK cells in some target cell combinations, indicating that the $\mathrm{CD} 2$ alternative activation pathway is also functional in NK cells $[14,89]$. The CD16 (FcyRIII) molecule represents the low-affinity receptor for the $\mathrm{Fc}$ fragment of $\mathrm{IgG}$, and is involved in antibody dependent cellular cytotoxicity (ADCC). The ability to mediate ADCC via CD16 points to a signal-transducing capacity of CD16 $[79,105,111]$. In NK cells the $\zeta$ chain is expressed in association with the CD16 molecule on the membrane and appears necessary for efficient surface expression of CD16 $[5,6,59]$.

\section{Non-TCR surface receptors involved in MHC-unrestricted cytolysis}

The putative receptors involved in MHC-unrestricted cytotoxicity have not as yet been identified. It has been suggested that multiple receptors are involved in target cell recognition and MHC-unrestricted cytotoxicity: the multireceptor model [47, 69]. In this model, lysis of target cells by activated lymphocytes can be triggered by the interplay of signals transduced by several cell-surface molecules that interact with their respective ligands on the target cell. The interactions between these molecules on the effector lymphocyte and the relative expression of their ligands on the target cell together determine whether or not the target cell will be lysed by the effector cell $[12,15,47]$.

The CD2 molecules serve as a functionally important interaction structure on TCR $\alpha \beta$, TCR $\gamma \delta$ and NK lymphocytes. As detailed earlier, CD2 mediates the adhesion of the effector to the target cell via binding to its natural ligand, i.e. LFA-3 or CD58, thereby contributing to antigen non-specific lymphocyte activation [96]. Three functionally important epitopes, T11.1, T11.2 and T11.3, have been identified on CD2 [70]. Only combinations of $\mathrm{mAb}$ directed against the CD2 epitopes T11.2 and T11.3 can induce IL- 2 dependent $\alpha \beta$ T cell proliferation; provide help for antibody responses, and induce antigen non-specific cytolytic activity by CTL $[14,54,109]$. Single anti$\mathrm{CD} 2 \mathrm{mAb}$ usually block $\alpha \beta \mathrm{T}$ cell activation and proliferation $[10,18]$. Recently it has been shown that upon $\mathrm{T}$ cell activation via $\mathrm{CD} 2$, the $\mathrm{CD} 2$ is not only functionally but also physically associated with the CD3 molecular complex $[21,72]$.

Other nonpolymorphic glycoproteins, such as CD3, CD16, and CD28, are also involved in the lymphocyte activation and triggering for lysis. Some of these structures are functionally interrelated, or they interact with the TCR $\alpha \beta$, TCR $\gamma \delta$ or putative NK lymphocyte receptor and with each other. This functional interplay between distinct activation sites suggests that their individual activation pathways, converge intracellularly $[3,13,72,105]$. All data thus strongly argue in favor of our previously published hypothesis that a multireceptor recognition process is involved in MHC-(un)restricted target-cell recognition and lysis [47]. Therefore, activation via one receptor can be enhanced via another using combinations of the relevant $\mathrm{mAb}[13,14,17,39,76,105]$.

\section{Grene organisation and protein structure of the $\mathbf{T}$ cell receptor and immunoglobulins}

The structures present in the immunesystem, which are capable of specific antigen recognition are 1) the surface bound or secreted Ig on B cells and 2) the TCR expressed by $T$ cells. The four distinct TCR chains $\alpha, \beta, \gamma, \delta$ form two different heterodimers $(\alpha \beta$ and $\gamma \delta)$.

The genomic organization of the TCR elements resembles that of the immunoglobulin gene superfamily. Also their quaternary structure shows great similarity [28].

\section{TCR and Ig genes}

Like the Ig light chain loci, the TCR $\alpha$ and $\gamma$ chain loci comprise a number of variable gene segments $(V)$, joining gene segments $(\mathrm{J})$ and one or more constant gene segments (C). The Ig heavy chain loci and the TCR $\beta$ and $\gamma$ chain loci comprise additional diversity gene segments (D) between the $\mathrm{V}$ and $\mathrm{J}$ clusters $[28,91]$. Functional TCR or Ig genes are assembled in an identical way in a two-step process of recombination. First, fusion of particular V, (D) and J segments within the DNA, by deletion of intervening sequences, creates a complete $\mathrm{V}$-coding domain upstream of the $\mathrm{C}$ gene segment(s). Second, after transcription of the entire gene, RNA-splicing enzymes splice the non-coding intron that separates the V(D)J and C gene segments. The resulting sequence of messenger RNA is translated into protein. Diversity of TCR and Ig is not only created by the joining of particular $\mathrm{V}$, (D), $\mathrm{J}$ and $\mathrm{C}$ gene segments but also by the random addition of nucleotides at the $V$-(D)- $J$ joining sites [57]. The contribution of somatic mutations on diversity is, however, specific for Ig [28]. 


\section{TCR and Ig protein structures}

Comparison of the primary sequence of TCR and Ig reveals that the residues that are principally responsible for the framework structure of the $\mathrm{V}$ regions are highly conserved [27]. This implies that TCR and Ig V regions fold in the same fashion, and that the chain pairing and the resulting combining sites of $\mathrm{V} \alpha-\mathrm{V} \beta$ and $\mathrm{V} \gamma-\mathrm{V} \delta$ are similar to those of $\mathrm{V}_{\mathrm{H}}-\mathrm{V}_{\mathrm{L}}$ combinations. The loops that form the antigen binding site in TCR are similar in size and location to those found in Ig but have different conformations. Also the structures at the $\mathrm{V}$-C interphase of TCR and Ig are very similar, indicating that the $\mathrm{V}$ and $\mathrm{C}$ domains of TCR and Ig fold in the same way. Recently it has been found that membrane-bound Ig are associated with two other transmembrane proteins, $\operatorname{IgM} \alpha$ and $\operatorname{Ig} \beta$, which form a disulphide-linked heterodimer [48]. In analogy to the TCR/CD3 relation, it was suggested that these proteins act as a signal transducer for the membrane bound Ig.

\section{Targeting of lymphocyte specificity}

Although most efforts to produce human CTL specific for human tumours have failed, many $\mathrm{mAb}$ are available that bind selectively, albeit not exclusively, to tumour cells. The combined use of CTL and tumour-selective $\mathrm{mAb}$, offered a novel approach to target the CTL to the tumor cells selectively. These engineered lymphocyte specificities may in the future play a key role in the destruction of tumour cells. The employment of (a) mAb, (b) bs-mAb or (c) chimeric Ig-TCR receptors to engineer lymphocyte specificity for targeting to tumour cells together with cytokines represents a promising approach.

\section{Monoclonal antibody targeting of cytotoxic Tlymphocytes}

As earlier detailed, CTL can only lyse target cells that express the relevant $\mathrm{Ag} / \mathrm{MHC}$ complex on their cell surface. However, CTL can also be induced to lyse target cells that they would normally not recognize and lyse [105]. This process is referred to as targeting of lymphocytes. For instance, anti-TCR/CD3 mAb can mimic the activation that occurs upon TCR-Ag/MHC recognition. Anti$\mathrm{TCR} / \mathrm{CD} 3 \mathrm{mAb}$ induces lysis of IgG-Fc-receptor-positive target cells because the mAb bridges the CTL and the target cell, and simultaneously activates the lytic machinery of the CTL $[62,105]$. Also mAb directed against other activation sites, such as CD2, CD16 and CD26, can induce lysis of target cells $[14,37,38,105]$.

\section{Bispecific mAb targeting of cytotoxic T lymphocytes}

An interesting exploitation of the phenomenon that $\mathrm{mAb}$ mediated lymphocyte activation results in triggering of the lytic machinery (see above) is the use of bs-mAb [78, 97]. Bs-mAb can be produced by chemically coupling a mAb that is specific for, e. g. the TCR complex to a second mAb, for example one specific for a given tumour-cell-associated antigen. Also chemically crosslinked antibodies have been produced with one binding site recognizing the CD16 activation site on NK cells and the other recognizing a tumour-associated antigen [50]. Such mAb heteroaggregates bridge the effector lymphocyte to the target cell (conjugate formation) and trigger the lymphocyte lytic machinery. In the latter example the heteroconjugated antibody triggers lymphocyte-mediated cytolysis by binding to CD16 via its Fab, rather than via its Fe portion.

Along the same line, many preparations of bs-mAb, that recognize the $\mathrm{CD} 3$ complex on the one hand and a tumourassociated antigen on the other (e.g. melanoma, renal, ovarian, lung and mammary carcinoma) have been developed $[24,60,102,106,107]$. Such bs-mAb have also been generated by fusion of two hybridomas that produce CD3/TCR-specific mAb or the target-cell-specific mAb respectively [71]. The hallmark of bs-mAb targeting is that the binding of the $b s-m A b$ to the, by their nature uniquely, specific CTL now targets the CTL with the bs-mAb specificity. These bs-mAb-targeted CTL can effectively be used for adoptive transfer of immunity [86].

Since $\mathrm{mAb}$ with specificity for particular lymphocyte activation sites exist that trigger different functions or lymphocyte subpopulations, their selective use allows the activation and expansion of particular subsets of lymphocytes and eliminates the need for prior isolation of these lymphocyte subsets. These laboratory-targeted immune lymphocytes are presently being used for locoregional clinical adoptive immunotherapy. We and others have recently started a phase I-II clinical trial employing bs-mAb-retargeted lymphocytes for the intraperitoneal treatment of ovarian carcinoma patients [73].

\section{Chimeric immunoglobulin-T cell receptor}

Bs-mAb-targeted T lymphocytes retain the antibody-dictated specificity only for limited periods of time $(6-72 \mathrm{~h})$, due to the dissociation of the bs-mAb from the cell surface [60] (Bolhuis, manuscript in preparation). In addition, it is not known whether the bs-mAb targeted lymphocytes can traffic, and eventually home to the tumour site. Thus, the bs-mAb targeted $\mathrm{T}$ lymphocytes may at this stage be therapeutically most effective when applied locoregionally. The systemic eradication of primary tumours and metastasis requires "long-lasting" and systemic immune responses. Molecular engineering of T lymphocytes can result in such permanently acquired, laboratory chosen, tumour selectivity of $\mathrm{T}$ lymphocytes, i.e. by the construction of chimeric Ig-TCR receptors. To become effective, such $T$ lymphocytes require not only the stable expression of the engineered Ig-TCR receptor at the lymphocyte surface, but also its functional association with the CD3 signal-transducing elements. This condition was met by the introduction and expression of chimeric Ig/TCR genes, in which the variable (V) gene segments of the TCR $\alpha$ and TCR $\beta$ chains were replaced by the variable gene segments of the heavy and light chain of an Ig with known specificity $[7,32,41-43]$. 
Transfection of the expression vectors containing these chimeric Ig/TCR genes in recipient mouse $T$ cell lines resulted in the synthesis of chimeric proteins which became stably and functionally expressed at the lymphocyte surface of the lymphocytes. Both combinations of complementary chimeric Ig/TCR genes, i. e. $\mathrm{V}_{\mathrm{H}}-\mathrm{C} \alpha+\mathrm{V}_{\mathrm{L}}-\mathrm{C} \beta$ or $\mathrm{V}_{\mathrm{H}}-\mathrm{C} \beta+\mathrm{V}_{\mathrm{L}}-\mathrm{C} \alpha$, appeared to yield a functional chimeric heterodimer $[43,56]$. Consequently, the chimeric receptor equiped the $\mathrm{T}$ lymphocytes with the antibody specificity which, of course, is MHC-unrestricted. These chimeric receptors were able to transduce signals for $\mathrm{T}$ cell activation, as determined by $\mathrm{Ca}_{\mathrm{i}}{ }^{2+}$ mobilization [56]; IL-2 production [32, 40-43]; proliferative response [40], and cytotoxic activity $[40,42,43]$.

Relatively large numbers of lymphocytes expressing the chimeric receptor are required for therapeutic applications. In order to reduce the need for prolonged lymphocyte expansion, it is important that a high percentage of lymphocytes can simultaneously be infected. Such a high multiplicity of infection also ensures that the genetically modified $T$ cells are polyclonal. This may be best achieved by retrovirus-mediated gene transfer, which can transduce a wide variety of cell types with a much higher efficiency than other procedures [26]. Another advantage of retrovirus-mediated gene transfer is that all proviral copies become stably integrated into the chromosomal DNA of the recipient cell. This chromosomal integration of the transduced gene guarantees the constitutive expression of chimeric Ig/TCR genes, a prerequisite for prolonged immune reactivity. Meanwhile, mouse and human T lymphocytes have been successfully transduced with a number of genes using retroviral vectors $[1,26,33,34,51,82]$.

Before clinical application of these genetically modified lymphocytes takes place we have to know whether the administration of these lymphocytes is safe. After all, foreign DNA is inserted randomly in the genome and this may theoretically initiate an oncogenic transformation. However, the results obtained in vitro in animals and those obtained after and during 56 months of observation of patients who received Neo-gene transfected autologous $\mathrm{T}$ lymphocytes in a phase I clinical protocol, have not revealed any abnormalities or side-effects.

\section{Concluding remarks}

The targeting of immune effector cells to tumour cells by bs-mAb or by chimeric Ig-TCR receptors offers potential clinical applications. Many questions still need to be answered:

Is the triggering for cytolysis by CTL important or is the induction of lymphokine production by CTL or non-CTL critical?

Can the targeted CTL traffic and home like physiologically activated $\mathrm{T}$ cells? Does lymphokine production at the tumour site cause "bystander" tumour cell lysis which prevents the escape of those tumour cells that lack the relevant tumour antigen expression?

Does "humanization" of the mouse mAb prevent or reduce human anti-mouse $A b$ responses that may block their therapeutic effect?
What are the optimal time schedules for administration of adoptive immunotherapy?

Data addressing these different questions are emerging. However, we should not delay clinical studies until all the questions have been answered, provided of course that the trials fulfil the accepted criteria of good laboratory and clinical practice.

\section{References}

1. Abraham N, Miceli M, Parnes JR, Veilette A (1991) Enhancement of $\mathrm{T}$-cell responsiveness by the lymphocyte-specific tyrosine protein kinase p56 $6^{\mathrm{ck}}$. Nature 350: 62

2. Alarcon I, Cuturi MC, Trinchieri G, Perussia B (1988) Interaction of $\mathrm{Fc}$ receptor (CD16) ligands induces transcription of interleukin 2 receptor (CD25) and lymphokine genes and expression of their products in human natural killer cells. J Exp Med 167: 452

3. Alcover A, Albertini C, Acuto O, Clayton LK, Transy C, Spagnoli GC, Moingeon P, Lopez P, Reinherz EL (1988) Interdependence of CD3-Ti and CD2 activation pathways in human $\mathrm{T}$ lymphocytes. EMBO J 7: 1973

4. Anderson P, Blue ML, Morimoto C, Schlossman SF (1987) Crosslinking of T3 (CD3) with T4 (CD4) enhances the proliferation of resting $\mathrm{T}$ lymphocytes. J Immunol 139: 678

5. Anderson PM, Caligiuri M, Ritz J, Schlossman SF (1989) CD3negative natural killer cells express $\zeta$ TCR as part of a novel molecular complex. Nature 341: 159

6. Anderson P, Caligiuri M, O'Brien C, Manley T, Ritz J, Schlossman SF (1990) Fc $\gamma$ receptor type III (CD16) is included in the $\zeta N K$ receptor complex expressed by human natural killer cells. Proc Natl Acad Sci USA 87: 2274

7. Becker MLB, Near R, Mudgett-Hunter M, Margolies MN, Kubo RT, Kaye J, Hedrick SM (1989) Expression of a hybrid immunoglobulin-T-cell receptor protein in transgenic mice. Cell 58: 911

8. Berke $\mathrm{G}$ (1980) Interaction of cytotoxic $\mathrm{T}$ lymphocytes and target cells. Prog Allergy 27:69

9. Biassoni R, Ferrini S, Prigione I, Moretta A, Long EO (1988) CD3 negative lymphokine activated cytotoxic cells express the CD3عgene. J Immunol 140: 1685

10. Bierer BE, Peterson A, Gorga JC, Herrmann SH, Burakoff SJ (1988) Synergistic T cell activation via the physiological ligands for CD2 and the T cell receptor. J Exp Med 168: 1145

11. Blue ML, Hafler DA, Craig KA, Levine H, Schlossman SF (1987) Phosphorylation of CD 4 and CD 8 molecules following T cell triggering. J Immunol 139: 3949

12. Bolhuis RLH, Braakman E (1988) Lymphocyte-mediated responses: activation of, and lysis by, cytotoxic lymphocytes. Curr Opinion Immunol 1: 236

13. Bolhuis RLH, Van de Griend RJ (1985) PHA induced proliferation and cytolytic activity in $\mathrm{T} 3^{+}$but not in $\mathrm{T} 3^{-}$cloned lymphocytes, requires the involvement of the $\mathrm{T} 3$ antigen for signal transmission. Cell Immunol 93: 46

14. Bolhuis RLH, Roozemond RC, van de Griend RJ (1986) Induction and blocking of cytolysis in $\mathrm{CD}_{2}{ }^{+}, \mathrm{CD}^{-} \mathrm{NK}$ and $\mathrm{CD}^{+}, \mathrm{CD}^{+}$ cytotoxic $\mathrm{T}$ lymphocytes via $\mathrm{CD} 2,50 \mathrm{kD}$ sheep erythrocyte recep tor. J Immunol 136: 3939

15. Bolhuis RLH, Gravekamp C, van de Griend RJ (1986) Cell-cell interactions. Clin Immunol Allerg 6: 29

16. Borst J, Van de Griend RJ, Van Oostveen H, Ang S, Melief CJM Seidman JG, Bolhuis RLH (1987) A T-cell receptor/CD3 complex found on cloned functional lymphocytes. Nature 325: 683

17. Braakman E, Goedegebuure PS, Vreugdenhil RJ, Segal DM, Shaw S, Bolhuis RLH (1990) ICAM- melanoma cells are relatively resistant to CD3 mediated T-cell lysis. Int J Cancer 46: 475

18. Breitmeyer JB, Daley JF, Levine HB, Schlossman SF (1987) The $\mathrm{T} 11$ (CD2) molecule is functionally linked to the $\mathrm{T} 3 / \mathrm{Ti} \mathrm{T}$ cell receptor in the majority of T cells. J Immunol 139: 2899 
19. Brenner MB, Towbridge IS, Strominger JL (1985) Crosslinking of human $\mathrm{T}$ cell receptor proteins. Association between $\mathrm{T}$ cell idiotypic $\beta$ subunits and the T3 glycoprotein heavy subunit. Cell 40 : 183

20. Brenner MB, McLean J, Dialynas DPB, Strominger JL, Smith JA, Owen FL, Seidman JG, Ip S, Rosen F, Krangel MS (1986) Identification of a putative second $T$-cell receptor. Nature 322: 145

21. Brown MH, Cantrell DA, Brattsand G, Crumpton MJ, Gullberg M (1989) The CD2 antigen associates with the T-cell antigen receptor CD3 antigen complex on the surface of human $\mathrm{T}$ lymphocytes. Nature 339: 551

22. Bubenik J, Jakoubkova J, Krakora P, Baresova M, Helbich P, Vicklicky V, Malaskova V (1971) Cellular immunity to renal carcinomas in man. Int J Cancer 8: 503

23. Burnet FM (1970) The concept of immunological surveillance. Prog Exp Tumor Res 13: 1

24. Canevari S, Ménard S, Mezzanzanica D, Miotti S, Pupa SM, Lanzavecchia A, Colnaghi MI (1988) Anti-ovarian carcinoma anti-T3 heteroconjugates or hybrid antibodies induce tumor cell lysis by cytotoxic T cells. Int J Cancer 42: 18

25. Cantrell D, Davies AA, Londei M, Feldman M, Crumpton MJ (1987) Association of phosphorylation of the T3 antigen with immune activation of $\mathrm{T}$ lymphocytes. Nature $325: 540$

26. Cepko CL, Roberts BE, Mulligan RC (1984) Construction and applications of a highly transmissible murine retrovirus shuttle vector. Cell 37: 1053

27. Chothia C, Boswell BW, Lesk AM (1988) The outline structure of the T-cell $\alpha \beta$ receptor. EMBO J 7: 3745

28. Davis MM, Bjorkman PJ (1988) T-cell antigen receptor genes and T-cell recognition. Nature 334: 395

29. Dembic Z, Haas W, Weiss S, McCubrey J, Kiefer H, Von Boehmer $H$, Steinmetz M (1986) Transfer of specificity by murine $\alpha$ and $\beta$ T cell receptor genes. Nature 320: 232

30. Dustin ML, Springer TA (1989) T-cell receptor cross-linking transiently stimulates adhesiveness through LFA-1. Nature 341: 619

31. Ehrlich P (1909) Über den jetzigen Stand der Karzinomforschung. Ned Tijdschr Geneesk 35: 273

32. Eshhar Z, Gross G (1990) Chimeric T cell receptor which incorporates the anti-tumor specificity of a monoclonal antibody with the cytolytic activity of $T$ cells: a model system for immunotherapeutical approach. Br J Cancer 62 [Suppl 10]: 27

33. Ferrari G, Rossini S, Giavazzi R, Maggioni D, Nobili N, Soldati M, Ungers G, Mavilio F, Gilboa E, Bordignon C (1991) An in vivo model of somatic cell gene therapy for human severe combined immunodeficiency. Science 251: 1363

34. Finn OJ, Persons DA, Bendt KM, Pirami L, Ricciardi P (1990) Retroviral transduction of protein kinase $\mathrm{C}-\gamma$ into cytotoxic $\mathrm{T}$ lymphocyte clones leads to immortalization with retention of specific function. J Immunol 146: 1099

35. Fisch P, Malkovsky M, Kovats S, Sturm E, Braakman E, Klein BS, Voss SD, Morrissey LW, DeMars R, Welch WJ, Bolhuis RLH, Sondel PM (1990) Recognition by human V $\gamma 9 / \mathrm{V} \delta 2 \mathrm{~T}$ cells of a GroEL homolog on Daudi Burkitt's lymphoma cells. Science 250: 1269

36. Fleisher B (1984) Acquisitions of specific cytotoxic activity by human T4+ T lymphocytes in culture. Nature 308: 365

37. Fleischer B, Sturm E, De Vries JE, Spits H (1988) Triggering of cytotoxic T lymphocytes and NK cells via the Tp103 pathway is dependent on the expression of the $\mathrm{T}$ cell receptor/CD3 complex. J Immunol 141: 1103

38. Goedegebuure PS, Segal DM, Braakman E, Vreugdenhil RJ, van Krimpen BA, van de Griend RJ, Bolhuis RLH (1989) Induction of lysis by $\mathrm{T}$ cell receptor $\gamma \delta^{+} / \mathrm{CD}^{+} \mathrm{T}$ lymphocytes via $\mathrm{CD} 2$ requires triggering via the T11.1 epitope only. J Immunol 142: 1797

39. Goedegebuure PS, Braakman E, Segal DM, Vreugdenhil RJ, Bolhuis RLH (1990) Lymphocyte leukocyte function-associated antigen-1 interacting with target cell intercellular adhesion molecule-1 coactivates cytolysis triggered via CD16 on the receptor involved or major histocompatibility antigen-unrestricted lysis. Int Immunol 2: 1213
40. Gorochov G, Gross G, Waks T, Eshhar Z (1990) Expression of chimeric $A b / T C R$ genes as functional receptor molecules in human and mouse $\mathrm{T}$ cells. In: Cellular immunity and the immunopathology of cancer, Lotz MT and Finn OJ (eds), Wiley-Liss Inc, New York, p 45

41. Goverman J, Gomez SM, Segesman KD, Hunkapiller T, Lang WE, Hood L (1990) Chimeric immunoglobulin-T-cell receptor complex formation and activation. Cell 60:929

42. Gross G, Gorochov G, Waks T, Eshhar Z (1989) Generation of effector $T$ cells expressing chimeric $T$ cell receptor with antibody type specificity. Transplant Proc 21: 127

43. Gross G, Waks T, Eshhar Z (1989) Expression of immunoglobulinT-cell receptor chimeric molecules as functional receptors with antibody-type specificity. Proc Natl Acad Sci USA 86: 10024

44. Haskins K, Kubo R, White J, Pigeon M, Kappler J, Marrack P (1983) The major histocompatibility complex restricted antigen receptor on $\mathrm{T}$ cells. Isolation with a monoclonal antibody. J Exp Med 161: 1513

45. Hedrick SM, Nielsen EA, Kavaler J, Cohen DI, Davis MM (1984) Sequence relationships between putative $T$ cell receptor polypeptides and immunoglobulins. Nature 308: 153

46. Hercend T, Schmidt RE (1988) Characteristics and uses of natural killer cells. Immunol Today 9: 291

47. Hersey P, Bolhuis RLH (1987) "Nonspecific" MHC-unrestricted killer cells and their receptors. Immunol Today 8: 233

48. Hombach J, Tsubata T, Leclercq L, Stappert H, Reth M (1990) Molecular components of the B-cell antigen receptor complex of the IgM class. Nature 343: 760

49. Hünig T, Kiefenthaler G, Meyer zum Buschenfelde KH, Meuer SC (1987) Alternative pathway activation of T cells by binding of CD2 to its cell-surface ligand. Nature 326: 298

50. Karpovsky B, Titus JA, Stephany DA, Segal DM (1984) Production of target-specific receptor cells using hetero-cross-linked-aggregates containing anti-target cell and anti-Fc $\gamma$ receptor antibodies. $\mathbf{J}$ Exp Med 160: 1686

51. Kasid A, Morecki S, Aebersold PM, Cornetta K, Culver K, Freeman S, Director E, Lotze MT, Blaese RM, Anderson WF, Rosenberg SA (1990) Human gene transfer: characterization of human tumor-infiltrating lymphocytes as vehicles for retroviralmediated gene transfer in man. Proc Natl Acad Sci USA 87: 473

52. Figdor CG, van Kooyk Y, Keizer GD (1990) On the mode of action of LFA-1. Immunol Today II: 277

53. Brenner MB, McLean J, Scheft H, Ruberdy J, Ang S-L, Seidman SG, Devlin P, Krangel MS (1987) Two forms of the T-cell receptor gamma protein found on peripheral blood cytotoxic $\mathrm{T}$ lymphocytes. Nature 325: 689

54. Krensky AM, Sanchez-Madrid F, Robbins E, Nagy JA, Springer TA, Burakoff SJ (1983) The functional significance, distribution, and structure of LFA-1, LFA-2 and LFA-3; cell surface antigens associated with CTL target interactions. J Immunol 131:611

55. Kupfer A, Singer SJ, Janeway CA, Swain SL (1987) Coclustering of CD4 (L3T4) molecule with the T-cell receptor is induced by specific direct interaction of helper $\mathrm{T}$ cells and antigen-presenting cells. Proc Natl Acad Sci USA 84: 5888

56. Kuwana $Y$, Asakura $Y$, Utsuomiya N, Nakanishi M, Arata Y, Itoh S, Nagase F, Kurosawa Y (1987) Expression of chimeric receptor composed of immunoglobulin-derived $\mathrm{V}$ regions and $\mathrm{T}$-cell receptor-derived C regions. Biochem Biophys Res Commun 149: 960

57. Lafaille JJ, DeCloux A, Bonneville M, Takagaki Y, Tonegawa S (1989) Junctional sequences of T cell receptor $\gamma \delta$ genes: implications for $\gamma \delta \mathrm{T}$ cell lineages and for a novel intermediate of $\mathrm{V}$-(D)-J joining. Cell 59: 859

58. Lanier LL, Dwirla S, Phillips JH (1986) Genomic organization of $\mathrm{T}$ cell $\gamma$ genes in human peripheral blood natural killer cells. J Immunol 137: 3375

59. Lanier LL, Yu G, Phillips JH (1989) Co-association of CD3ל with a receptor (CD16) for IgG on human natural killer cells. Nature 342 : 803

60. Lanzavecchia A, Scheidegger D (1987) The use of hybrid hybridomas to target human cytotoxic T lymphocytes. Eur J Immunol 17: 105 
61. Leeuwenberg J, Spits H, Tax W, Capel P (1985) Monoclonal antibodies against $\mathrm{T} 3$ induce antigen non specific cellular cytotoxicity. J Immunol 134: 3770

62. Leeuwenberg JFM, Lems SPM, Capel PJA (1987) Anti-T3 induced cytotoxicity: the role of target cell Fc-receptors in the lysis of autologous monocytes and the Fc-independent lysis of T3-positive target cells. Transplant Proc 19: 428

63. Littman DR (1987) The structure of the CD4 and CD8 genes. Annu Rev Immunol 5: 561

64. Makgoba MW, Sanders ME, Luce GEG, Dustin ML, Springer TA, Clark EA, Mannoni P, Shaw S (1988) ICAM-1 a ligand for LFA-1 dependent adhesion of B-, T- and myeloid cells. Nature 331: 86

65. Marlin SD, Springer TA (1987) Purified intercellular adhesion molecule-1 (ICAM-1) is a ligand for lymphocyte function-associated antigen 1(LFA-1). Cell 51: 813

66. Marrack P, Kappler J (1986) The antigen specific, major histocompatibility complex restricted receptor on T cells. Adv Immunol 38: 1

67. Martz E (1977) Mechanisms of specific tumor cell lysis by alloimmune $\mathrm{T}$ lymphocytes; resolution and characterization of discrete steps in the cellular interaction. Contemp Top Immunobiol 7: 301

68. Menzer SJ, Smith BR, Barbosa SA, Crimmins MAV, Herrmann SH, Burakoff SI (1987) CTL adhesion and antigen recognition are discrete steps in the human CTL target cell interaction. J Immunol 138: 1325

69. Meuer SC, Schlossman SF, Reinherz EL (1982) Clonal analysis of human cytotoxic $\mathrm{T}$ lymphocytes: $\mathrm{T}^{+}$and $\mathrm{T} 8^{+} \mathrm{T}$ cells recognize products of different major histocompatibility complex regions. Proc Natl Acad Sci USA 79: 4395

70. Meuer SC, Russey RE, Fabbi M, Fox D, Acuto D, Fitzgerald KA, Hodgdon JC, Protentis JP, Schlosmann SF, Reinherz EL (1984) An alternative pathway of $\mathrm{T}$ cell activation: a functional role for the $50 \mathrm{kD}$ T1 1 sheep erythrocyte receptor protein. Cell $36: 897$

71. Milstein C, Cuello AC (1983) Hybrid hybridomas and their use in immunohistochemistry. Nature 305: 537

72. Moingeon P, Chang HC, Wallner BP, Stebbins C, Frey AZ, Reinherz EL (1989) CD 2 mediated adhesion facilitates T-lymphocyte antigen recognition function. Nature 339: 312

73. Nitta T, Sato K, Yagita H, Okumura K, Ishii S (1990) Preliminary trial of specific targeting therapy against malignant glioma. Lancet 335: 368

74. Oettgen HC, Kappler J, Tax WJM, Terhorst C (1984) Characterization of the two heavy chains of the T3 complex on the surface of human T lymphocytes. J Biol Chem 259: 12039

75. Ortaldo JR, Herberman RB (1984) Heterogeneity of natural killer cells. Annu Rev Immunol 2: 359

76. Pantaleo G, Olive D, Poggi A, Pozzan T, Moretta L, Moretta A (1987) Antibody-induced modulation of the CD3/T-cell receptor complex causes $\mathrm{T}$-cell refractoriness by inhibiting the early metabolic steps involved in T-cell activation. J Exp Med 166: 619

77. Parnes JR (1989) Molecular biology and function of CD4 and CD8. Adv Immunol 44: 265

78. Perez P, Hoffman RW, Shaw S, Bluestone JA, Segal DM (1985) Specific targeting of cytotoxic T-cells by anti-T3 linked to anti-target cell antibody. Nature 316: 354

79. Perussia B, Trinchieri G, Jackson A, Warner NL, Faust J, Rumpold H, Kraft D, Lanier LL (1984) The Fc receptor for IgG on human natural killer cells: phenotype, functional, and comparative studies with monoclonal antibodies. J Immunol 133: 180

80. Phillips JH, Le AM, Lanier LL (1984) Natural killer cells activated in a human mixed lymphocyte response culture identified by expression of Leu-11 and class II histocompatibility antigens. J Exp Med 159: 993

81. Ritz J, Schmidt RE, Michon J, Hercend T, Schlossman SF (1988) Characterization of functional surface structures on human natural killer cells. Adv Immunol 42: 181

82. Rosenberg SA, Aebersold PM, Cornetta K, Kasid A, Morgan RA, Moen R, Karson EM, Lotze MT, Yang JC, Topalian SL, Merino MJ, Culver K, Miller AD, Blaese RM, Anderson WF (1990) Gene transfer into humans: immunotherapy of patients with advanced melanoma, using tumor-infiltrating lymphocytes modified by retroviral gene transduction. N Engl J Med 323: 570

83. Rosenstein Y, Ratnofsky S, Burakoff SJ, Herrmann SH (1989) Direct evidence for binding of CD8 to HLA class I antigens. J Exp Med 169: 149

84. Saito T, Weis TA, Miller J, Norcross MA, Germain N (1987) Specific antigen-Ia activation of transfected human T cells expressing murine TCR $\alpha \beta$ human T3 complexes. Nature 325: 125

85. Saizawa K, Rojo J, Janeway Jr JA (1987) Evidence for a physical association of $\mathrm{CD} 4$ and the $\mathrm{CD} 3: \alpha: \beta$ T-cell receptor. Nature 328: 260

86. Segal DM, Snider DP (1989) Targeting and activation of cytotoxic lymphocytes. Chem Immunol 47:179

87. Selvaraj PM, Plunkett L, Dustin M, Sanders ME, Shaw S, Springer TA (1987) The T lymphocyte glycoprotein CD2 binds the cell surface ligand LFA-3. Nature 326: 400

88. Shaw S, Luce GEG, Quinones R, Gress RE, Springer TA, Sanders ME (1986) Two antigen-independent adhesion pathways used by human cytotoxic T-cell clones. Nature 323: 262

89. Siciliano RF, Pratt JC, Schmidt RE, Ritz J, Reinherz EL (1985) Activation of cytolytic $T$ lymphocytes and natural killer cell function through the T11 sheep erythrocyte binding protein. Nature 317: 428

90. Sim GK, Yague J, Nelson J, Marrack P, Palmer E, Augustin A, Kappler J (1984) Primary structure of human T cell receptor $\alpha$ chain. Nature 312: 771

91. Siu G, Clark SP, Yoshikai Y, Malissen M, Yanagi Y, Strauss E Mak TW, Hood L (1984) The human T cell antigen receptor is encoded by variable, diversity, and joining gene segments that rearrange to generate a complete $V$ gene. Cell 37: 393

92. Sleckman BP, Peterson A, Jones WK, Foran JA, Greenstein JL, Seed B, Burakoff SJ (1987) Expression and function of CD4 in a murine $T$ cell hybridoma. Nature 328: 626

93. Spits H, Yssel H, Voordouw A, de Vries JE (1985) The role of T8 in the cytotoxic $T$ lymphocyte lines specific for class $\Pi$ and class I major histocompability complex antigens. J Immunol 134: 2294

94. Spits H, Schooten W, Keizer H, van Seventer G, van de Rijn M, Terhorst C, de Vries JE (1986) Alloantigen recognition is preceeded by nonspecific adhesion of cytotoxic $\mathrm{T}$ cells and target cells. Science 232: 403

95. Spits H, Yssel H, de Vries JE (1990) Analysis of specificity of human TCR $\gamma \delta^{+}$T cells. Res Immunol 141: 636

96. Springer TA, Dustin ML, Hishimoto TK, Marlin SD (1987) The lymphocyte function associated LFA-1, CD2, and LFA-3 molecules: cell adhesion receptors of the immune system. Annu Rev Immunol 5: 223

97. Staertz UD, Kanagawa O, Bevan MJ (1985) Hybrid antibodies can target sites for attack by T-cells. Nature 314: 628

98. Staunton DE, Dustin ML, Springer TA (1989) Functional cloning of ICAM-2, a cell adhesion ligand for LFA-1 homologous to ICAM-1. Nature 339: 61

99. Sturm E, Braakman E, Bontrop RE, Chuchana P, Van de Griend RJ, Koning F, Lefranc MP, Bolhuis RLH (1989) Coordinated Vy and $\mathrm{V} \delta$ genesegment rearrangements in human T-cell receptor $\gamma \delta \mathrm{lym}$ phocytes. Eur J Immunol 19: 1261

100. Sturm E, Braakman E, Fisch P, Vreugdenhil RJ, Sondel P, Bolhuis RLH (1990) Human V $\gamma_{9}-\mathrm{V} \delta 2 \mathrm{~T}$ cell receptor $-\gamma \delta$ lymphocytes show specificity to Daudi Burkitt's lymphoma cells. J Immunol 145: 3202

101. Swain SL (1983) T cell subsets and the recognition of MHC class. Immunol Rev 74: 129

102. Titus JA, Garrido MA, Hecht TT, Winkler DF, Wunderlich JR, Segal DM (1987) Human T-cells targeted with anti-T3 cross-linked to antitumor antibody prevent tumor growth in nude mice. Immunology 138: 4018

103. Trinchieri G (1989) Biology of natural killer cells. Adv Immunol 47: 187

104. Trinchieri G, Matsumoto-Kobayashi M, Clark SC, Sheera J, London L, Perussia B (1984) Response of resting human peripheral blood natural killer cells to interleukin-2. J Exp Med 160: 1147 
105. Van de Griend RJ, Bolhuis RLH, Stoter G, Roozemond R (1987) Regulation of cytolytic activity in $\mathrm{CD}^{-}$and $\mathrm{CD} 3^{+}$killer cell clones by monoclonal antibodies (anti-CD16, anti-CD2, anti-CD3) depends on the subclass specificity of target cell IgG-FcR. J Immunol 138: 3137

106. Van de Griend RJ, Tax WJM, Van Krimpen BA, Vreugdenhil RJ, Ronteltap CPM, Bolhuis RLH (1987) Lysis of tumor cells by CD $3^{+}$ 4-8-16+ T cell receptor $\alpha \beta$ clones, regulated via CD3 and CD16 activation sites, recombinant interleukin 2 and interferon $\beta$. J Immunol 138: 1627

107. Van Dijk J, Tsuruo T, Segal DM, Bolhuis RLH, Colognola R, Van de Griend RJ, Fleuren GJ, Warnaar SO (1989) Bispecific antibodies reactive with the multidrug-resistance-related glycoprotein and CD3 induce lysis of multidrug-resistant tumor cells. Int J Cancer 44: 738

108. Van Dijk J, Warnaar SO, Van Eendenburg JDH, Thienpont M, Braakman E, Boot JHA, Fleuren GJ, Bolhuis RLH (1989) Induction of tumor-cell lysis by bi-specific monoclonal antibodies recognizing renal cell carcinoma and CD3 antigen. Int J Cancer 43: 344
109. Van Wauwe J, Goosens J, DeCock W, Kung P, Goldstein G (1981) Suppression of human $\mathrm{T}$ cell mitogenesis and E-rosette formation by the monoclonal antibody OKT11A. Immunology 41: 865

110. Vose BM, White W (1983) Tumour-reactive lymphocytes stimulated in mixed lymphocyte and tumour culture. Cancer Immunol Immunother 15: 227

111. Werfel T, Uciechowski P, Tetteroo PAT, Kurrle R, Deicher H, Schmidt RE (1989) Activation of cloned human natural killer cells via FcyRIII. J Immunol 142: 1102

112. Wright SC, Bonavida B (1982) Studies on the mechanism of natural killer (NK) cell-mediated cytotoxicity (CMC) release of cytotoxic factors specific for NK-sensitive target cells (NKCF) during coculture of NK effector cells with NK target cells. J Immunol 129: 433

113. Yanagi Y, Yoshikai Y, Leggett K, Clark SP, Aleksander I, Mak TW (1984) A human T cell specific cDNA clone encodes a protein having extensive homology to immunoglobulin domains. Nature 308: 145

114. Young DEJ, Liu CC (1988) Multiple mechanisms of lymphocytemediated killing. Immunol Today 9: 140 